\title{
Impact of anode substrates on electrodeposited zinc over cycling in zinc-anode rechargeable alkaline batteries
}

\author{
Xia Wei ${ }^{\mathrm{a} *}$, Divyaraj Desai ${ }^{\mathrm{a}, \mathrm{b}}$, Gautam G. Yadav ${ }^{\mathrm{a}}$, Damon E. Turney ${ }^{\mathrm{a}}$, \\ Alexander Couzis $^{\mathrm{a}}$, Sanjoy Banerjee ${ }^{\mathrm{a}}$
}
${ }^{a}$ CUNY Energy Institute \& Department of Chemical Engineering, The City College of New York, New York, USA, 10031
${ }^{\mathrm{b}}$ Palo Alto Research Center, a Xerox company, USA, 94304
*Corresponding author should be addressed to Dr. Xia Wei
Email: xwei@ccny.cuny.edu \& lunaweixia@gmail.com (X. Wei)

Tel: +1-347-404-0409

\begin{abstract}
Electrochemical behavior of $\mathrm{Ag}, \mathrm{Bi}, \mathrm{Cu}, \mathrm{Fe}, \mathrm{Ni}$ and $\mathrm{Sn}$ substrates on zinc deposition was evaluated over battery cycling by cyclic voltammetry and electrochemical impedance spectroscopy. The effect of $\mathrm{Bi}, \mathrm{Cu}, \mathrm{Ni}$, and $\mathrm{Sn}$ substrates on zinc electrodeposition during battery cycling was investigated using scanning electron microscopy and X-ray diffraction. The corrosion behavior of each metal in $9 \mathrm{M} \mathrm{KOH}$ and the corrosion rates of zinc plated on each substrate were analyzed by Tafel extrapolation method from the potentiodynamic polarization curves and electrochemical impedance spectroscopy. Although the charge-transfer resistance $\left(\mathrm{R}_{\mathrm{ct}}\right)$ of zinc electrodeposition is lowest on Sn, Sn eventually corrodes on cycling in alkaline media. Use of $\mathrm{Ni}$ as a substrate causes zinc to deteriorate on account of rapid hydrogen evolution. $\mathrm{Bi}$ and $\mathrm{Cu}$ substrates are more suitable for use as current collectors in zinc-anode alkaline
\end{abstract}


rechargeable batteries because of their low corrosion rate and compact zinc deposition over battery cycling.

Key words: Zinc; Alkaline batteries; Electrodeposition; Substrates

\section{Introduction}

Use of zinc as the anode for alkaline rechargeable batteries has gained attention due to zinc's low cost, high specific energy density, high equilibrium potential, ease of handling and environmental friendliness [1]. Zinc anodes are being developed for a number of commercial applications including small consumer products and large grid-scale battery backup systems [1]. To current date, commercialized technologies of zinc anodes are not capable of cycling more than 500 cycles at high depth of discharge (DOD) without deep cleaning step and more than several thousand cycles at low DOD, such as $10 \%[1,2]$. Recently, a novel "flow assisted" zinc-nickel battery was proven to cycle it's zinc anodes at $\sim 95 \%$ DOD for $3000+$ cycles in small batteries and $1000+$ cycles in a large $36 \mathrm{kWh}$ demonstration [3].

However, one of the main challenges that hinder the widespread use of rechargeable zinc anodes is the formation of porous or dendritic zinc during cycling, which leads to battery failure. Various approaches have been applied to avoid this problem and obtain compact zinc deposits [4-10]. Previous research has focused on the impact of current density and flow rate on the zinc morphology [11-13], additives in the electrode and electrolyte [1417], separator improvement [18], pulse charging and electrode vibration [18]. 
Various metal substrates have been used to improve the efficiency of zinc deposition either by increasing the overvoltage of the parasitic hydrogen evolution reaction (HER), accelerating zinc deposition kinetics or altering the crystal habit of electrodeposited zinc [19-21]. HER gas formation has been shown to affect the zinc deposit morphology [2224]. Morphology of zinc electrodeposition also has a preferred crystal orientation that is dependent on current density and electrolyte mass transfer properties [25]. Each plane of zinc crystal has a corresponding free energy of electrodeposition, which generates different corrosion resistance on the various crystal faces [26]. For example, the preferred orientation of zinc on brass $(11 \overline{2} 2)$ correlates with a high coulombic efficiency $\left(95 \%^{+}\right)$ during battery cycling [25]. The early stage of compact zinc electrodeposition was also studied on carbon-coated TEM grids [27], where it was demonstrated that $(00 \overline{0} 2)$ zinc single-crystals merge to form polycrystalline compact zinc thin films. It has also been reported [19] that crystallographic mismatch between the substrate and zinc deposit affects the zinc adhesion and subsequent morphology, in particular that islands of zinc form on substrates of larger crystallographic misfit. Therefore, zinc deposits are finegrained on $\mathrm{Cu}$ but are large boulders on $\mathrm{Fe}$ and $\mathrm{Ni}$. Chu et al. [20] and McBreen et al. [21] explored zinc deposition on various substrates from zincate solution, including $\mathrm{Cu}$, $\mathrm{Au}, \mathrm{Cd}, \mathrm{Pb}, \mathrm{Ti}, \mathrm{Sn}$ and $\mathrm{In} . \mathrm{Pb}$ and $\mathrm{Cd}$ substrates have been used commercially in rechargeable zinc electrodes since they produce adherent zinc deposits, inhibit zinc dendrite growth and suppress zinc corrosion (i.e. self-discharge). However, both $\mathrm{Pb}$ and $\mathrm{Cd}$ have environmental problems that have ended their widespread commercial use. Due to all these interactions, the choice of substrate plays a strong role in the performance, 
cycle life and commercial viability of zinc anodes, especially when zinc is plated on the bare substrate at the start of each cycle.

Much of the past work that is applicable to zinc electrodeposition is unclear whether the same predictions can be extended to long-term cycling in batteries. Substrate effects were only investigated on shallow charging. Deep cycling has not been investigated previously. On extended cycling it is seen that some substrates cause zinc deposits to rapidly degrade, making it impossible to use them during the typical cycling potentials observed in alkaline zinc anodes. In this work, the aim is to investigate the effect of environmental friendly substrates on zinc cycling performance.

\section{Experimental}

Cyclic voltammetry, impedance measurements and corrosion studies were performed on a rotating disk electrode setup, using PTFE encased $5 \mathrm{~mm}$ diameter rods of $\mathrm{Ag}, \mathrm{Bi}, \mathrm{Cu}$, $\mathrm{Fe}$, Ni and $\mathrm{Sn}(99.9 \%+$ pure $)$ purchased from Alfa Aesar. The electrodes were successively polished with 400,600, 1200-grit sandpaper, and then finished with 1 micron and 0.05 micron alumina polishing powder. The potential readings of all the experiments were measured against $\mathrm{Hg} \mid \mathrm{HgO}$ reference electrode (Koslow). The electrolyte was $60 \mathrm{~g} / \mathrm{L} \mathrm{ZnO}(0.74 \mathrm{~mol} / \mathrm{L})$ dissolved in $37 \%$ potassium hydroxide $(9 \mathrm{~mol} / \mathrm{L}$ $\mathrm{KOH})$. The $\mathrm{KOH}$ solution was freshly prepared by dissolving analytical reagent (AR)grade $\mathrm{KOH}$ (Sigma-Aldrich) pellets in deionized water. In order to imitate the real battery operation, the electrolytes were not deaerated. For zinc-anode battery system, the main challenge that accompanies with zinc deposition is hydrogen formation on the anode 
during charging. Hence, deaerating the electrolyte does not affect the observation significantly. A Pine Instrument MSR-type rotator at $100 \mathrm{rpm}$ was used in all the experiments, except for the cyclic voltammetry experiments and studies of corrosion rate where $0 \mathrm{rpm}$ was used. A Versastat 4 potentiostat (Princeton Applied Research) and an EC-potentiostat (Bio-logic Science Instruments) were used for all the electrochemical behavior experiments.

To measure the evolution of roughness and porosity (compactness) during many cycles of electrodeposited zinc, flat sheets $\left(6.45 \mathrm{~cm}^{2}\right)$ of $\mathrm{Bi}, \mathrm{Cu}, \mathrm{Ni}$ and $\mathrm{Sn}$ were used as the anode substrates in a prismatic flow-assisted cell with a $3 \mathrm{~mm}$ gap between the cathode and anode. The setup of prismatic flow-assisted cell is the same as our previous studies $[11,28,29]$. Bi sheets were prepared by physical vapor deposition of $\mathrm{Bi}$ onto $\mathrm{Cu}$ sheets. Galvanostatic (constant current) cycling experiments were carried out using an Arbin BT2000 battery tester. The electrolyte was $0.74 \mathrm{M} \mathrm{ZnO}$ dissolved in $9 \mathrm{M} \mathrm{KOH}$ solution. The electrolyte flows from the bottom to the top of the cell at a flow velocity of $0.8 \mathrm{~cm} / \mathrm{s}$. Current densities of the galvanostatic experiments were $12.5 \mathrm{~mA} / \mathrm{cm}^{2}, 25 \mathrm{~mA} / \mathrm{cm}^{2}$ and $37.5 \mathrm{~mA} / \mathrm{cm}^{2}$. The cross-section of zinc deposition morphology on each substrate at the specified current densities was examined in a scanning electron microscope (SEM) at charge density of $50 \mathrm{C} / \mathrm{cm}^{2}$ and $100 \mathrm{C} / \mathrm{cm}^{2}$ after the first and sixth charge cycles. The sample treatment procedure is described elsewhere [11]. Briefly, the samples were treated with epoxy and cured after which they were cut in three segments, and the cross section of zinc morphology of each segment was examined by a Zeiss Supra 55 VP FE-SEM. Xray diffraction (XRD) was used to investigate the effect of substrates on the 
crystallographic orientation of zinc deposition morphology during cycling. XRD experiments were carried out in a Philips Panalytical diffractometer operating at 40 $\mathrm{kV} / 40 \mathrm{~mA}$ from 30 to 140 degree with a $\mathrm{Cu}-\mathrm{K} \alpha$ filter at a scan rate of 0.188 degree/s.

\section{Results and Discussion}

\subsection{Electrochemical analysis}

\subsubsection{Cyclic voltammetry}

Cyclic voltammograms of disk electrodes of our various substrates were scanned at 10 $\mathrm{mV} / \mathrm{s}$ from $-1.8 \mathrm{~V}$ to $0.2 \mathrm{~V}$, as shown in Fig. 1. These data present cathodic and anodic peaks of zinc deposition and dissolution. In the cathodic direction, the onset potentials for zinc deposition on $\mathrm{Ag}, \mathrm{Cu}$ and $\mathrm{Sn}$ are slightly higher than that on other metals, indicating that $\mathrm{Ag}, \mathrm{Cu}$ and $\mathrm{Sn}$ are more facile for zinc to deposit on. It is observed that hydrogen bubbles evolve more readily on $\mathrm{Ni}[30,31]$. Hydrogen $\left(\mathrm{H}_{2}\right)$ evolution imbalances the cathode versus anode and causes loss of coulombic and energy efficiency. Hydrogen evolution is more drastic during the first cycle relative to subsequent cycles. In table 1, typical hydrogen overvoltages at current density $1 \mathrm{~mA} / \mathrm{cm}^{2}$ on the metal substrates are reported [30,31]. The higher hydrogen overvoltage is indicative of less hydrogen evolving on the metal substrate. Fe and $\mathrm{Ni}$ electrodes have earlier $\mathrm{H}_{2}$ evolution due to the low activation overpotential [30,31].

In the anodic direction, additional oxidation peaks are observed, indicating the dissolution of an alloy or oxide phase. For example on Ag substrate, in the anodic sweep 
direction peak $\mathrm{Zn}_{\mathrm{a}}$ occurs at $-1.3 \mathrm{~V}$ due to the dissolution of metallic zinc, then other anodic peaks $\mathrm{Ag}_{\mathrm{aI}}$ and $\mathrm{Ag}_{\text {aII }}$ appear at $-1.15 \mathrm{~V}$ vs. $\mathrm{Hg} \mid \mathrm{HgO}$ and $-0.31 \mathrm{~V}$ vs. $\mathrm{Hg} \mid \mathrm{HgO}$, respectively. Peak $\mathrm{Ag}_{\mathrm{al}}$ was ascribed to $\varepsilon$-phase alloy $\mathrm{AgZn}_{3}$ and peak $\mathrm{Ag}_{\text {aII }}$ is to $\zeta$-phase alloy $\mathrm{AgZn}_{3}$ by Hendrikx et al. [32]. These two alloy peaks are formed through diffusion [32]. During the cathodic sweep at $0.15 \mathrm{~V}$ vs. $\mathrm{Hg} \mid \mathrm{HgO}$ peak $\mathrm{Ag}_{\mathrm{cI}}$ takes place, which is ascribed to $\mathrm{Ag}$ reduction reaction. For $\mathrm{Bi}$ substrate, in the cathodic direction, $\mathrm{Bi}$ deposition forms the cathodic peak near $-0.7 \mathrm{~V}$ vs. $\mathrm{Hg} \mid \mathrm{HgO}$ then it deposits at its limiting current density from $-0.8 \mathrm{~V}$ to $-1.4 \mathrm{~V}$ vs. $\mathrm{Hg} \mid \mathrm{HgO}$ [33]. During the anodic sweep $\mathrm{Bi}$ oxidation occurs at $-0.37 \mathrm{~V}$ vs. $\mathrm{Hg} \mid \mathrm{HgO}$. During zinc deposition on $\mathrm{Cu}$, a cathodic shoulder at $-1.1 \mathrm{~V}$ is seen, which was attributed to underpotential deposition of zinc [34]. By comparison, Sn does not show underpotential deposition or alloys with zinc. The current-voltage relationship for a $\mathrm{Sn}$ electrode in $9 \mathrm{M} \mathrm{KOH}$ and $0.74 \mathrm{M} \mathrm{ZnO}$ solution shows that during the cathodic scan an anodic peak $\mathrm{Sn}_{\mathrm{cI}}$ rises around $-0.92 \mathrm{~V}$ vs. $\mathrm{Hg} \mid \mathrm{HgO}$, which likely exists due to destruction of a passivation layer that was previously prohibiting the electrochemical dissolution of tin. Peak $\mathrm{Sn}_{\mathrm{cII}}$ is where $\mathrm{Sn}$ reduction reaction happens [35]:

$\mathrm{SnO}_{2}(s)+\mathrm{H}_{2} \mathrm{O}+2 e^{-} \rightleftharpoons \mathrm{SnO}(s)+2 \mathrm{OH}^{-} \quad \mathrm{E}_{0}=-1.059 \mathrm{~V}$ vs. $\mathrm{Hg} \mid \mathrm{HgO}$

The anodic peak $\mathrm{Sn}_{\mathrm{aI}}$ and the shoulder $\mathrm{Sn}_{\text {aII }}$ are due to electro-dissolution and formation of a passivation layer respectively. A precipitation of $\mathrm{SnO}$ or $\mathrm{Sn}(\mathrm{OH})_{2}$ is formed at the electrode surface, which corresponds to peak $\mathrm{Sn}_{\mathrm{aI}}[36]$. 
Zinc dissolution is most pronounced on $\mathrm{Sn}$ substrate, followed by $\mathrm{Fe}, \mathrm{Ag}, \mathrm{Ni}, \mathrm{Bi}$ and $\mathrm{Cu}$. While $\mathrm{Bi}$ has similar electrochemical properties as $\mathrm{Pb}$, it is much less toxic and stable in alkaline media. $\mathrm{Fe}$ and $\mathrm{Ni}$ are not recommended because of their tendency toward hydrogen evolution, although several previous papers successfully use nickel substrates at high coulombic efficiency for thousands of cycles [3]. Based on the cyclic voltammetry data, $\mathrm{Ag}, \mathrm{Bi}, \mathrm{Cu}$ and $\mathrm{Sn}$ are the most promising anode substrates of this group for zinc rechargeable alkaline batteries.

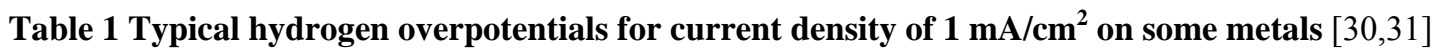

\begin{tabular}{ccccccc}
\hline Metal & $\mathrm{Ag}$ & $\mathrm{Bi}$ & $\mathrm{Cu}$ & $\mathrm{Fe}$ & $\mathrm{Ni}$ & $\mathrm{Sn}$ \\
Overpotential $\eta / \mathrm{V}$ & 0.475 & 0.78 & 0.45 & 0.4 & 0.3 & 0.75 \\
\hline
\end{tabular}

\subsubsection{Electrochemical Impedance Spectroscopy and corrosion tests}

Cyclic electrochemical Impedance Spectroscopy (EIS) experiments were carried out to compare the charge transfer resistance $\mathrm{R}_{\mathrm{ct}}$ of the bare substrates over 50 cycles of zinc deposition and dissolution. The applied EIS potential amplitude was $5 \mathrm{mV}$ placed on top of a steady $-1.45 \mathrm{~V}$ to maintain the zinc deposition process. The EIS frequency range was $100 \mathrm{KHz}$ to $10 \mathrm{~Hz}$. For each of the 50 cycles, zinc was deposited on each substrate for 1 $\mathrm{C}\left(5 \mathrm{C} / \mathrm{cm}^{2}\right)$ at $-1.45 \mathrm{~V}$ then deplated galvanostatically at $25 \mathrm{~mA} / \mathrm{cm}^{2}$ until the potential dropped to -1.1 V. EIS measurements were collected after each deplating was completed. Charge transfer resistance at the end of each cycle was determined from the impedance plot. In Fig. 2a, $\mathrm{Bi}$ is found to have high $\mathrm{R}_{\mathrm{ct}}$ at the first few cycles but it improves over cycling. Slow kinetics at the first few cycles was probably due to the formation of $\mathrm{Bi}$ 
layer prior to zinc deposition. Sn has the lowest $R_{c t}$, and $R_{c t}$ is stable on $A g$ over cycling. The increase of $\mathrm{R}_{\text {ct }}$ on $\mathrm{Cu}$ gradually during cycling may result from the depleting of zinc underpotential deposition. Fe anode fails on account of rapid hydrogen evolution and $\mathrm{Ni}$ anode deteriorates due to high charge transfer resistance $R_{c t}$. $R_{c t}$ of substrates over zinc deposition/dissolution increases in the order: $\mathrm{Sn}<\mathrm{Bi}<\mathrm{Ag}<\mathrm{Cu}<\mathrm{Ni}<\mathrm{Fe}$ over battery cycling. The corrosion current densities $\left(i_{\text {corr }}\right)$ of the different substrates in $9 \mathrm{M} \mathrm{KOH}$ solution were measured by potentiodynamic polarization technique. This method may only approximate and provide an upper bound on the corrosion rate, and cannot distinguish between dissolution of metal or formation of surface oxide films, but it is still helpful for comparison on the relative electrochemical activity of the different substrates. The potential scan $(v=0.166 \mathrm{mV} / \mathrm{s})$ was performed without stirring the solution, starting from a potential $250 \mathrm{mV}$ more cathodic than the corrosion potential and then followed by scanning in the anodic direction towards $250 \mathrm{mV}$ more anodic than the corrosion potential. Each experiment was performed at least three times. The Tafel polarization curves were obtained and shown in Fig. $2 b$. The corrosion current densities $\left(i_{\text {corr }}\right)$ were obtained from the Tafel plots by extrapolating the linear portion of the curve to the corrosion potential. Table 2 shows the results of the corrosion parameters for each substrate in $9 \mathrm{M} \mathrm{KOH}$ solution based on this method. The estimated upper bound on corrosion rates decrease in the order: $\mathrm{Sn}>\mathrm{Bi}>\mathrm{Cu}>\mathrm{Ag}>\mathrm{Ni}>\mathrm{Fe}$. However, $\mathrm{Ni}$ and $\mathrm{Fe}$ have comparable values. 
Table 2 Parameters for the corrosion of metal substrates in $9 \mathrm{M} \mathrm{KOH}$ solution

\begin{tabular}{ccccc}
\hline Substrates & $\mathrm{E}_{\text {corr. }} / \mathrm{mV}$ vs. $\mathrm{Hg} \mid \mathrm{HgO}$ & $i_{\text {corr. }} \mu \mathrm{A} / \mathrm{cm}^{2}$ & $\beta_{\mathrm{a}} \mathrm{mV}$ & $\beta_{\mathrm{c}} \mathrm{mV}$ \\
\hline $\mathrm{Ag}$ & 150.022 & 8.499 & 104.1 & 121.8 \\
$\mathrm{Bi}$ & -571.879 & 46.219 & 18.7 & 98.4 \\
$\mathrm{Cu}$ & -492.317 & 17.973 & 41 & 58.1 \\
$\mathrm{Fe}$ & -982.018 & 1.224 & 74.9 & 54.1 \\
$\mathrm{Ni}$ & -213.645 & 1.612 & 103.7 & 86.6 \\
$\mathrm{Sn}$ & -1099.671 & 93.908 & 30.1 & 273.9 \\
\hline
\end{tabular}

Additional EIS measurements were collected to compare the charge transfer resistance $\mathrm{R}_{\mathrm{ct}}$ of zinc deposits covering the different substrates, before and after a 12-hour rest in the electrolyte. During EIS measurements the substrate was held at an applied potential amplitude of $5 \mathrm{mV}$ placed on top of a steady voltage which is equal to OCV. The frequency range was $100 \mathrm{KHz}$ to $10 \mathrm{~Hz}$. Before collecting the EIS measurements, zinc was deposited on each metal substrate for $10 \mathrm{C}\left(50 \mathrm{C} / \mathrm{cm}^{2}\right)$ at $25 \mathrm{~mA} / \mathrm{cm}^{2}$. Figs. $2 \mathrm{c}$ and $2 \mathrm{~d}$ compare the Nyquist plots of zinc deposition on different substrates before and after a rest in $\mathrm{KOH}$ for 12 hours. Fig. 2e shows the equivalent electrical circuit used for the EIS plots. Charge transfer resistances were calculated based on the equivalent circuit and are shown in table 3. It indicates that after zinc deposits on different anode substrates, the corrosion rates of zinc decrease in order: $\mathrm{Fe}>\mathrm{Ni}>\mathrm{Sn}>\mathrm{Cu}>\mathrm{Bi}>\mathrm{Ag}$. Also, after the cells rest for 12 hours, the corrosion rates of zinc deposition decrease in order: $\mathrm{Ni}>\mathrm{Fe}>\mathrm{Cu}>\mathrm{Sn}>\mathrm{Bi}>\mathrm{Ag}$. Since zinc deposited on nickel dissolves back to solution within the 12-hour rest, it demonstrates that zinc on $\mathrm{Ni}$ is more corrosive. It also has good agreement well with the result from the OCV measurement shown in Fig. 3. 
Table 3 Charge transfer resistance $\mathbf{R}_{\mathrm{ct}}$ of zinc deposition on different anode substrates

\begin{tabular}{ccc}
\hline Substrate & \multicolumn{2}{c}{$\mathrm{R}_{\mathrm{ct}} / \mathrm{ohms}$} \\
\hline $\mathrm{Ag}$ & No rest & 12 hours rest \\
$\mathrm{Bi}$ & 35.94 & 15.06 \\
$\mathrm{Cu}$ & 22.19 & 12.13 \\
$\mathrm{Fe}$ & 6.33 & 3.10 \\
$\mathrm{Ni}$ & 1.93 & 2.15 \\
$\mathrm{Sn}$ & 2.15 & - \\
\hline
\end{tabular}

The zinc was deposited galvanostatically on $\mathrm{Ag}, \mathrm{Bi}, \mathrm{Cu}, \mathrm{Ni}$ and $\mathrm{Sn}$ in $9 \mathrm{M} \mathrm{KOH}$ with $0.74 \mathrm{M} \mathrm{ZnO}$ solution with a geometric area of $0.2 \mathrm{~cm}^{2}$ for charge density $50 \mathrm{C} / \mathrm{cm}^{2}$ at 25 $\mathrm{mA} / \mathrm{cm}^{2}$ then were left for rest at OCV for 12 hours then deplated. Electro-dissolution proceeded under $25 \mathrm{~mA} / \mathrm{cm}^{2}$ until the voltage reached $-1.3 \mathrm{~V}$ vs. $\mathrm{Hg} \mid \mathrm{HgO}$. Fig. 3 demonstrates the self-discharge of zinc deposited on the various substrates. It indicates that zinc deposition could maintain the expected potential on $\mathrm{Ag}, \mathrm{Bi}, \mathrm{Cu}, \mathrm{Fe}$ and $\mathrm{Sn}$. Corrosion of zinc was provoked on $\mathrm{Ni}$ substrate. To compare the corrosion of zinc deposition on substrates, same tests were also conducted on substrates except for resting zinc deposition for 12 hours. Table 4 demonstrates even though Fe maintains the expected potential, zinc corrodes drastically on Fe. The results from table 4 indicate that corrosion of zinc on $\mathrm{Fe}$ and $\mathrm{Ni}$ are pronounced, while it is comparable on $\mathrm{Bi}, \mathrm{Cu}$ and $\mathrm{Sn}$. Ag substrate is the least for zinc to corrode. 
Table 4 Corrosion of zinc deposition on substrates during OCV

\begin{tabular}{cccc}
\hline & $\begin{array}{c}\text { Coulombic efficiency \% } \\
\text { (No OCV rest) }\end{array}$ & $\begin{array}{c}\text { Coulombic efficiency \% } \\
(12 \text { hours OCV rest) }\end{array}$ & $\begin{array}{c}\text { Amount of zinc } \\
\text { corrodes at OCV (\%) }\end{array}$ \\
\hline $\mathrm{Ag}$ & 100 & 90.1 & 9.9 \\
$\mathrm{Bi}$ & 99.6 & 76.8 & 22.8 \\
$\mathrm{Cu}$ & 100 & 76.6 & 23.4 \\
$\mathrm{Fe}$ & 96.2 & 13.8 & 82.4 \\
$\mathrm{Ni}$ & 90.7 & - & 90.7 \\
$\mathrm{Sn}$ & 99.5 & 77.5 & 22 \\
\hline
\end{tabular}

\subsection{Substrates performance on battery cycling}

\subsubsection{Coulombic efficiency measurements}

The substrate metal has a strong effect on the performance of zinc anodes, especially at the earliest stage of zinc electrodeposition due to their diverse $\mathrm{H}_{2}$ evolution rate and impact on the crystal orientation of zinc deposition. Rotating disk electrodes (RDE) were used to investigate the performance of $\mathrm{Ag}, \mathrm{Bi}, \mathrm{Cu}, \mathrm{Fe}, \mathrm{Ni}$ and $\mathrm{Sn}$ substrates on zinc plating and deplating. The amount of charge passed in all the experiments was $5 \mathrm{C} / \mathrm{cm}^{2}$. Fig 4a shows the performance of the metal substrates tested on the first cycle at different current densities. Rotation speed of RDE was set at $100 \mathrm{rpm}$ for each experiment, corresponding to a mass-transfer limiting current density of $55 \mathrm{~mA} / \mathrm{cm}^{2}$, and the chosen current densities were fractions of this limiting current density. Electro-dissolution proceeded until the voltage reached $-1.3 \mathrm{~V}$ vs. $\mathrm{Hg} \mid \mathrm{HgO}$. Fig. $4 \mathrm{a}$ indicates that $\mathrm{Sn}$ has the 
best performance amongst these anode substrates at various current densities. Other anode substrates demonstrate better performance on zinc deposition/dissolution efficiency at current density ratio of 0.4-0.45.

In Fig. 4b, zinc deposition was cycled where each cycle was defined by deposition at -20 $\mathrm{mA} / \mathrm{cm}^{2}$ until $5 \mathrm{C} / \mathrm{cm}^{2}$ were passed and then dissolution at $25 \mathrm{~mA} / \mathrm{cm}^{2}$ until the voltage reached $-1.3 \mathrm{~V}$. The results indicate that $\mathrm{Fe}$ and $\mathrm{Ni}$ do not have desirable performance due to hydrogen evolution, which is hypothesized due to HER gas becoming trapped on the downward-facing rotating electrode surface. These results agree with the cyclic voltammogram experiments. The hydrogen evolution on $\mathrm{Fe}$ and $\mathrm{Ni}$ was visible with the naked eyes. Ni and Fe anodes failed within 50 cycles. The coulombic efficiencies were $95 \%+$ for $\mathrm{Ag}, \mathrm{Bi}, \mathrm{Cu}$ and $\mathrm{Sn}$ substrates. However, as we stated before, we note that $3000+$ cycles are achievable in different flow and cycling conditions when $\mathrm{Ni}$ is applied as the substrate [3].

\subsubsection{Gas measurements}

Hydrogen evolution as a parasitic reaction happening together with zinc deposition leads to decrease of energy efficiency. The anode substrate plays an important role in this reaction. Hydrogen generation rates on $\mathrm{Ag}, \mathrm{Bi}, \mathrm{Cu}, \mathrm{Fe}, \mathrm{Ni}$ and $\mathrm{Sn}$ were tested in a fully sealed prismatic cell with an upside down graduated cylinder [37]. It is a typical method of measuring gas generation. The volume of water pushed out from the graduated cylinder corresponds to the volume of hydrogen generated on charging. Since the batteries were not operated under the potential region where oxygen generation happens; 
hence, the gas that was being collected was mainly hydrogen. In this way, the rate of hydrogen evolution is determined. A sintered $\mathrm{Ni}(\mathrm{OH})_{2}$ cathode was used, with a capacity of $0.18 \mathrm{Ah}$. The electrodes were $1 \mathrm{in}^{2}$ and the electrolyte was $9 \mathrm{M} \mathrm{KOH}$ mixed with 0.74 $\mathrm{M} \mathrm{ZnO}$. The amount of coulombs charged in the cell during charging was $50 \mathrm{C} / \mathrm{cm}^{2}$. The charging current density is $25 \mathrm{~mA} / \mathrm{cm}^{2}$ and the discharge current density is (calculated from Ni cathode capacity which is might not be relevant) $28 \mathrm{~mA} / \mathrm{cm}^{2}$. The gas generated during cycling displaces the water out from the cylindrical tube. The volume of excluded water during a certain time is the way of expressing gas generation rate (Table 5). Less gas is generated on $\mathrm{Ag}, \mathrm{Bi}$ and $\mathrm{Cu}$. Gas evolves drastically on $\mathrm{Ni}$. Fe generates less gas than Ni but hosts high HER compared to other substrates. Initially, Sn does not initiate gas formation; however, with increasing cycle life, it becomes highly active for HER, and this is likely because Sn degrades in alkaline solution. As a result, zinc corrodes quickly on Sn during battery cycling. Hydrogen generation occurs not only as a competitive reaction during zinc deposition but also occurs during $\mathrm{OCV}$ and discharging as a pair reaction of zinc corrosion. $\mathrm{Ag}, \mathrm{Bi}, \mathrm{Cu}$ and $\mathrm{Sn}$ are suitable as anode substrates in zincanode rechargeable batteries to suppress hydrogen evolution. 
Table 5 Gas generation rate $(\mu \mathrm{L} / \mathrm{min})$ on anode metals

\begin{tabular}{lccc}
\hline & $1^{\text {st }}$ charge & $5^{\text {th }}$ charge & $10^{\text {th }}$ charge \\
\hline $\mathrm{Ag}$ & 2.15 & 1.67 & 1.45 \\
$\mathrm{Bi}$ & 2.03 & 3.78 & 3.95 \\
$\mathrm{Cu}$ & 3.15 & 3.38 & 2.87 \\
$\mathrm{Fe}$ & 2.79 & 4.15 & 4.12 \\
$\mathrm{Ni}$ & 11.13 & 13.42 & 14.25 \\
$\mathrm{Sn}$ & 2.54 & 4.23 & 4.57 \\
& & & \\
\hline
\end{tabular}

\subsection{Zinc deposition characterization}

\subsubsection{Surface roughness of zinc deposition on different anode substrates}

A prismatic flow-assisted cell was used to study the evolution of roughness and porosity of zinc electrodeposition on $\mathrm{Bi}, \mathrm{Cu}, \mathrm{Ni}$ and $\mathrm{Sn}$. The limiting current density of plane electrodes in the walls of a flow channel is also given by equation

$$
\begin{aligned}
& i_{\lim }=\frac{n F D C_{0}}{d_{e}} S h \\
& S h=1.85 \operatorname{Re}^{1 / 3} S c^{1 / 3}\left(d_{e} / L\right)^{1 / 3}
\end{aligned}
$$

where $i_{\text {lim }}$ is the limiting current density, $n$ is the number of electrons in the reaction, $F$ is Faraday's constant, $D$ is the diffusion coefficient, which is reported as $8 \times 10^{-6} \mathrm{~cm}^{2} / \mathrm{s}$ [38], $C_{0}$ is the bulk zinc concentration, $S h$ is Sherwood number, $R e$ is Reynolds number, $S c$ is 
Schmidt number, $d_{\mathrm{e}}$ is the hydraulic diameter and $L$ is the plate length in the streamwise direction. According to the equation, the limiting current density of this configuration was $-55 \mathrm{~mA} / \mathrm{cm}^{2}$ and it was also confirmed by linear potential sweep technique, which is a way to measure the mass transfer limiting current density.

The zinc morphologies were correlated to the ratio of current density to limiting current density $\left(i / i_{\text {lim }}\right)$. In addition, the minimum of total cell resistance $R_{\text {tot }}$ is reported to occur around $i / i_{\lim }=0.5$ [25]. The current densities of our experiments were $12.5 \mathrm{~mA} / \mathrm{cm}^{2}, 25$ $\mathrm{mA} / \mathrm{cm}^{2}$ and $37.5 \mathrm{~mA} / \mathrm{cm}^{2}$, which correspond to $\mathrm{i} / i_{\lim }$ of $0.23,0.45$ and 0.68 , respectively. Fig. 5 shows the cross-sectioned images of zinc deposition on $\mathrm{Bi}, \mathrm{Cu}, \mathrm{Ni}$ and $\mathrm{Sn}$ at the first and the sixth cycles separately. In these images the zinc deposits appear as darker grey and the metal substrates as the brightest grey. Compact zinc appeared lighter grey, and porous branched mossy zinc appeared darker. Figs. $6 \mathrm{a}$ and $6 \mathrm{~b}$ show the compact layer thickness of zinc deposition formed on $\mathrm{Bi}, \mathrm{Cu}, \mathrm{Ni}$ and $\mathrm{Sn}$ at the first and the sixth cycles when charge densities $50 \mathrm{C} / \mathrm{cm}^{2}$ and $100 \mathrm{C} / \mathrm{cm}^{2}$ were put in. Sn forms the thickest compact layer of zinc. $\mathrm{Cu}$ and $\mathrm{Bi}$ have similar compact zinc morphology. Figs. $6 \mathrm{c}$ and $6 \mathrm{~d}$ demonstrate the overall porosities of zinc deposition on metal anodes. The porosities of zinc electrodeposition were calculated based on the cross-sectioned SEM images by using Image $\mathrm{J}$ software. Zinc deposition formed on $\mathrm{Ni}$ has the highest porosity due to hydrogen formation. The order of porosities of zinc deposition on each metal is $\mathrm{Ni}>\mathrm{Bi}>\mathrm{Cu}>\mathrm{Sn}$. However, with cycling the porosities of zinc deposition on $\mathrm{Bi}$ and $\mathrm{Cu}$ are close to each other, and also, Sn has the least tendency for zinc to form high porous morphology. The zinc deposition on $\mathrm{Ni}$ is highly porous. The high porosity of zinc 
deposition makes electron transfer difficult, which is due to the low local current density, zinc deposition occurs close to $\mathrm{OCV}$, and has a higher kinetic resistance.

Fig. 7 shows the surface morphology of zinc deposition on $\mathrm{Ni}, \mathrm{Cu}, \mathrm{Bi}$ and $\mathrm{Sn}$. More closely stacked zinc has higher coulombic efficiency and high corrosion resistance. Deposition of zinc on Sn has layer-like structure. Zinc deposition on Bi and Sn is in the form of stacked plates. More compact deposition was found when $\mathrm{Bi}, \mathrm{Cu}$ and $\mathrm{Sn}$ were used as substrates compared to Ni. As a result of hydrogen formation, porous zinc generates more easily on $\mathrm{Ni}$ substrate that was also shown in the X-ray spectrum afterwards.

\subsubsection{XRD and preferred orientation results}

The crystal texture of zinc deposition has been related to zinc corrosion [39-43]. X-ray diffraction was applied to study the texture feature of zinc deposition formed on $\mathrm{Bi}, \mathrm{Cu}$, $\mathrm{Ni}$ and Sn sheets with 1 in $^{2}$ surface area. XRD patterns of zinc deposition on different anode substrates at different charge density and different cycle numbers in Fig. 8 demonstrate the evolution of texture feature of zinc morphology.

The preferred orientation was reported in terms of a texture coefficient (TC). Preferred orientation of electrodeposited zinc was quantified and the textured coefficients [44] of each reflection face were calculated as following:

$\mathrm{TC}=\frac{\frac{I_{h k l}}{I_{h k l}^{0}}}{\left(\frac{1}{n}\right) \sum\left(\frac{I_{h k l}}{I_{h k l}^{0}}\right)}$ 
where $I_{h k l}$ and $I_{h k l}^{0}$ are the crystal face (hkl) diffraction integral intensity of the deposit and the standard sample respectively; $\mathrm{n}$ is the number of the reflection faces in diffraction spectroscopy. TC values of each sample were reported in table 6 and table 7. A value of $\mathrm{TC}>1$ demonstrates preferred orientation of the plane is present in the sample.

Table 6 TC values of each orientation of zinc deposition on different substrates at $25 \mathrm{~mA} / \mathrm{cm}^{2}$

\begin{tabular}{|c|c|c|c|c|c|c|c|c|}
\hline & & $(002)$ & (100) & (101) & (102) & (103) & $(110)$ & (112) \\
\hline & $\mathrm{Ni}$ & 0.981 & 0.994 & 0.761 & 1.268 & 1.425 & 1.519 & 2.414 \\
\hline $1^{\text {st }}$ & $\mathrm{Cu}$ & 0.451 & 1.439 & 0.281 & 1.632 & 2.124 & 1.595 & 2.502 \\
\hline \multirow[t]{3}{*}{ Charge } & $\mathrm{Bi}$ & 1.754 & 0.787 & 0.231 & 2.369 & - & 5.319 & 2.482 \\
\hline & $\mathrm{Sn}$ & 0.875 & 1.089 & 0.562 & 3.407 & - & 1.743 & 4.359 \\
\hline & $\mathrm{Ni}$ & 0.814 & 0.972 & 0.678 & 1.616 & 1.021 & 1.804 & 3.127 \\
\hline $6^{\text {th }}$ & $\mathrm{Cu}$ & 0.737 & 1.337 & 0.732 & 1.256 & 1.563 & 1.606 & 1.893 \\
\hline \multirow[t]{2}{*}{ Charge } & $\mathrm{Bi}$ & 0.817 & 1.339 & 0.405 & 2.276 & 2.945 & 2.709 & 2.632 \\
\hline & $\mathrm{Sn}$ & 0.882 & 0.921 & 0.895 & 1.645 & 1.443 & 0.875 & 1.248 \\
\hline
\end{tabular}


Table 7 TC values of each orientation of zinc deposition on different substrates at $37.5 \mathrm{~mA} / \mathrm{cm}^{2}$

\begin{tabular}{|c|c|c|c|c|c|c|c|c|}
\hline & & $(002)$ & (100) & $(101)$ & $(102)$ & (103) & $(110)$ & (112) \\
\hline & $\mathrm{Ni}$ & 0.449 & 0.433 & 0.453 & 1.458 & - & 9.485 & 3.213 \\
\hline $1^{\mathrm{st}}$ & $\mathrm{Cu}$ & 1.959 & - & 0.522 & 2.214 & 2.543 & - & 2.877 \\
\hline \multirow[t]{3}{*}{ Charge } & $\mathrm{Bi}$ & 0.982 & 0.401 & 0.611 & 2.413 & - & 3.964 & 2.999 \\
\hline & $\mathrm{Sn}$ & - & - & 0.442 & 5.851 & - & - & 10.345 \\
\hline & $\mathrm{Ni}$ & 0.931 & 0.971 & 0.937 & 1.227 & - & 1.571 & 1.638 \\
\hline $6^{\text {th }}$ & $\mathrm{Cu}$ & - & 0.539 & 1.053 & - & - & 3.643 & 3.834 \\
\hline \multirow[t]{2}{*}{ Charge } & $\mathrm{Bi}$ & 0.839 & 0.971 & 1.053 & 1.279 & - & 1.136 & 1.646 \\
\hline & $\mathrm{Sn}$ & 0.909 & 1.057 & 0.906 & 1.439 & 1.473 & 1.295 & 1.935 \\
\hline
\end{tabular}

The texture of zinc depositions demonstrated that (002) basal plane has the highest corrosion resistance. Pangarov [45] stated that (100) crystal plane is dominant under intermediate current density. It has been found that texture of zinc deposition on different substrates varies. At $25 \mathrm{~mA} / \mathrm{cm}^{2}$, high angle prismatic (100) orientation was inhibited when zinc was deposited on $\mathrm{Bi}$ or Sn, i.e. high energy and lower packing density. When using Sn substrate, low energy basal plane (002) was suppressed and high angle pyramidal (112) orientation was provoked. Low energy high atomic packing plane (002) was increased when $\mathrm{Bi}$ and $\mathrm{Cu}$ were being used as substrates. Low angle pyramidal orientation (103) was increased on Bi substrate. Since Bi substrate was prepared by physical vapor depositing $\mathrm{Bi}$ on $\mathrm{Cu}$, there were some planes corresponding to $\mathrm{Cu}$ peaks as well. On Ni substrate, zinc crystal structure matches the pure zinc powder diffraction 
that has no texture. The absence of texture on Ni substrate corresponds to mossy zinc morphology. When zinc was cycled for the $6^{\text {th }}$ time, low energy high packing density basal plane (002) and prismatic plane (100) were promoted on $\mathrm{Bi}$ and $\mathrm{Cu}$. Pyramidal plane (112) was inhibited on $\mathrm{Cu}$. The texture of zinc deposition has good agreement with zinc morphology. Zinc deposition on Bi and Sn contains more basal planes and pyramidal planes that have higher corrosion resistance.

\section{Conclusion}

The effects of $\mathrm{Ag}, \mathrm{Bi}, \mathrm{Cu}, \mathrm{Fe}, \mathrm{Ni}$ and $\mathrm{Sn}$ substrates on electrodeposited zinc were studied by using cyclic voltammetry technique, electrochemical impendence spectroscopy, and linear polarization method. $\mathrm{Bi}$ was found to have higher $\mathrm{R}_{\mathrm{ct}}$ at the beginning but it improves with time. Sn has the lowest $\mathrm{R}_{\mathrm{ct}}$, while the $\mathrm{R}_{\mathrm{ct}}$ is stable on $\mathrm{Ag}$ over cycling. $\mathrm{Cu}$ has low $\mathrm{R}_{\mathrm{ct}}$ at the beginning however it increases with cycling. Ni anodes deteriorate on account of rapid hydrogen evolution. Corrosion rates of metal anodes in $9 \mathrm{M} \mathrm{KOH}$ solution decrease in the order: $\mathrm{Sn}>\mathrm{Bi}>\mathrm{Cu}>\mathrm{Ag}>\mathrm{Ni}>\mathrm{Fe}$. Although $\mathrm{Sn}$ has the highest coulombic efficiency, it degrades over cycling. The porosity of zinc deposition on metal anodes decrease in the order: $\mathrm{Ni}>\mathrm{Bi}>\mathrm{Cu}>\mathrm{Sn}$. Considering price of metals and performance of metal substrates in zinc-anode rechargeable flow batteries, $\mathrm{Bi}$ and $\mathrm{Cu}$ are the best choices for zinc anode substrate.

\section{Acknowledgments}

The support of the Department of Energy (ARPA-E grant No. DE-AR0000150) and the National Science Foundation (NSF grant no 1031820) is gratefully acknowledged. The 
authors would like to express their gratitude to Dr. Jorge Morales and Dr. Alexey Bykov, both from The City College of New York, for their assistance in analyzing the samples.

\section{References}

[1] D. Linden, T.B. Reddy, Handbook of batteries, third ed., 2001.

[2] D. Coates, E. Ferreira, A. Charkey, Development of a Long Cycle Life Sealed Nickel-Zinc Battery for High Energy-Density Appications, IEEE AES Syst. Mag. (1997) 35-38.

[3] D.E. Turney, M. Shmukler, K. Galloway, M. Klein, Y. Ito, T. Sholklapper, et al., Development and testing of an economic grid-scale flow-assisted zinc/nickelhydroxide alkaline battery, J. Power Sources. 264 (2014) 49-58. doi:10.1016/j.jpowsour.2014.04.067.

[4] K. Bass, P. Mitchell, G. Wilcox, Methods for the reduction of shape change and dendritic growth in zinc-based secondary cells, J. Power Sources. 35 (1991) 333351. http://www.sciencedirect.com/science/article/pii/037877539180117G.

[5] R.D. Naybour, The Effect of Electrolyte Flow on the Morphology of Zinc Electrodeposited from Aqueous Alkaline Solution Containing Zincate Ions, J. Electrochem. Soc. 116 (1969) 520-524. doi:10.1149/1.2411939.

[6] L. Zhang, J. Cheng, Y. Yang, Y. Wen, X. Wang, G. Cao, Study of zinc electrodes for single flow zinc/nickel battery application, J. Power Sources. 179 (2008) 381387. doi:10.1016/j.jpowsour.2007.12.088.

[7] Y. Ito, M. Nyce, R. Plivelich, M. Klein, D. Steingart, S. Banerjee, Zinc morphology in zinc-nickel flow assisted batteries and impact on performance, J. 
Power Sources. 196 (2011) 2340-2345. doi:10.1016/j.jpowsour.2010.09.065.

[8] A.P. Pavlov, L.K. Grigorieva, S.P. Chizhik, V.K. Stankov, Nickel-zinc batteries with long cycle life, J. Power Sources. 62 (1996) 113-116. doi:10.1016/S03787753(96)02421-4.

[9] X. Wei, A. Couzis, S. Banerjee, Zinc electrodeposition in Zinc-Nickel FlowAssisted Batteries, in: 222nd ECS Meet., Honolulu, Hawaii, 2012.

[10] Y. Ito, D. Desai, X. Wei, D.A. Steingart, S. Banerjee, Zinc Morphology in Zinc Nickel-Oxide Batteries, in: 220th ECS Meet., Boston, Massachusetts, 2011: p. 700.

[11] Y. Ito, X. Wei, D. Desai, D. Steingart, S. Banerjee, An indicator of zinc morphology transition in flowing alkaline electrolyte, J. Power Sources. 211 (2012) 119-128. doi:10.1016/j.jpowsour.2012.03.056.

[12] J.W. Gallaway, D. Desai, A. Gaikwad, C. Corredor, S. Banerjee, D. Steingart, A Lateral Microfluidic Cell for Imaging Electrodeposited Zinc near the Shorting Condition, J. Electrochem. Soc. 157 (2010) A1279. doi:10.1149/1.3491355.

[13] X. Wei, A. Couzis, S. Banerjee, Zinc Electrodeposition in Zinc-Nickel FlowAssisted Batteries, in: Chem. Eng. Approaches to Challenges Energy Biomed. Meet., The New York Academy of Sciences, New York, New York, 2012.

[14] J. Zhu, Y. Zhou, C. Gao, Influence of surfactants on electrochemical behavior of zinc electrodes in alkaline solution, J. Power Sources. 72 (1998) 231-235. doi:10.1016/S0378-7753(97)02705-5.

[15] F. Galvani, I.A. Carlos, The Effect of the Additive Glycerol on Zinc Electrodeposition on Steel, Met. Finish. (1997) 5-7. 
[16] S.J. Banik, R. Akolkar, Suppressing Dendrite Growth during Zinc Electrodeposition by PEG-200 Additive, J. Electrochem. Soc. 160 (2013) D519D523. doi:10.1149/2.040311jes.

[17] J.W. Gallaway, A.M. Gaikwad, B. Hertzberg, C.K. Erdonmez, Y.-C.K. ChenWiegart, L.A. Sviridov, et al., An In Situ Synchrotron Study of Zinc Anode Planarization by a Bismuth Additive, J. Electrochem. Soc. 161 (2013) A275A284. doi:10.1149/2.037403jes.

[18] F.R. Mclarnon, E.J. Cairns, The Secondary Alkaline Zinc Electrode, J. Electrochem. Soc. 138 (1991) 645-664.

[19] R.Y. Wang, D.W. Kirk, G.X. Zhang, Effects of Deposition Conditions on the Morphology of Zinc Deposits from Alkaline Zincate Solutions, J. Electrochem. Soc. 153 (2006) C357. doi:10.1149/1.2186037.

[20] M.G. Chu, J. McBreen, G. Adzic, Substrate Effects on Zinc Deposition from Zincate Solutions, J. Electrochem Soc. 128 (1981) 2281-2286.

[21] J. Mcbreen, M.G. Chu, G. Adzic, Substrate Effects on Zinc Deposition from Zincate Solutions, J. Electrochem. Soc. 128 (1981) 2287-2292.

[22] R.E.F. Einerhand, W.H.M. Visscher, E. Barendrecht, Hydrogen production during zinc deposition from alkaline zincate solutions, J. Appl. Electrochem. 18 (1988) 799-806.

[23] T. Trisovic, L.J. Gajic-Krstajic, N. Krstajic, On the kinetics of the hydrogen evolution reaction on zinc in sulfate solutions *, J. Serb. Chem. Soc. 66 (2001) $811-823$.

[24] Y. Ito, M. Nyce, R. Plivelich, M. Klein, S. Banerjee, Gas evolution in a flow- 
assisted zinc-nickel oxide battery, J. Power Sources. 196 (2011) 6583-6587. doi:10.1016/j.jpowsour.2011.03.025.

[25] D. Desai, X. Wei, D.A. Steingart, S. Banerjee, Electrodeposition of preferentially oriented zinc for flow-assisted alkaline batteries, J. Power Sources. 256 (2014) 145-152. doi:10.1016/j.jpowsour.2014.01.026.

[26] G.X. Zhang, Corrosion and electrochemistry of zinc, 1st ed., Springer $\begin{array}{llll}\text { Science+Business } & \text { Media, } & \text { LLC, }\end{array}$ http://books.google.com/books?hl=en\&lr=\&id=Qmf4VsriAtMC\&oi=fnd\&pg=PR1 $9 \& \mathrm{dq}=$ Corrosion + and + electrochemistry + of + Zinc \&ots=3Y8am9G4cD\&sig=yOe8t KjjGkLQmBM7G9B7I72YEAk.

[27] D. Desai, D.E. Turney, B. Anantharaman, D.A. Steingart, S. Banerjee, Morphological Evolution of Nanocluster Aggregates and Single Crystals in Alkaline Zinc Electrodeposition, J. Phys. Chem. C. 118 (2014) 8656-8666. doi:10.1021/jp411104a.

[28] X. Wei, S. Banerjee, Effect of Novel Substrates on Zinc Anode - Secondary Alkaline Battery Performance, Meet. Abstr. (2014) 98. http://ma.ecsdl.org/content/MA2014-01/1/98.abstract.

[29] X. Wei, A. Couzis, S. Banerjee, Improving zinc anode secondary alkaline battery performance using novel substrates, in: New York Batter. Energy Storage Technol. Conf., Syracuse, New York, 2013.

[30] E.W. Washburn, International Critical Tables, Natl. Acad. Sci. 6 (1929) 339-340.

[31] D.E.J. Talbot, J.D.R. Talbot, Corrosion Science and Technology, 2nd ed., n.d.

[32] J. Hendrikx, W. Visscher, E. Barendrecht, Interaction of zinc deposited from an 
alkaline solution with a polycrystalline silver substrate, Electrochim. Acta. 28 (1983) 743-749.

[33] B. Gollas, A. Luegger, J. Zidar, The Electrodeposition of Zinc-Bismuth Alloys, ECS Trans. 50 (2013) 123-133. doi:10.1149/05052.0123ecst.

[34] I.T. Bae, Alloy Formation at Electrodeposited Zinc-Copper Electrode Interfaces at Room Temperature, J. Electrochem. Soc. $155 \quad$ (2008) D395. doi:10.1149/1.2891134.

[35] S.A. Awad, A. Kassab, Mechanism of anodic dissolution of tin in sodium hydroxide solutions, Electroanal. Chem. Interfacial Electrochem. 26 (1970) $127-$ 135 .

[36] B.N. Stirrup, N.A. Hampson, The active dissolution of tin in concentrated alkaline solution, J. Electroanal. Chem. 67 (1976) 57-67.

[37] C. Li, Separating out hydrogen of zinc and its measurement in $\mathrm{KOH}$ solution, Chinese Batter. Ind. 6 (2001) 56-59.

[38] R.Y. Wang, D.W. Kirk, G.X. Zhang, Effects of Deposition Conditions on the Morphology of Zinc Deposits from Alkaline Zincate Solutions, J. Electrochem. Soc. 153 (2006) C357-364. doi:10.1149/1.2186037.

[39] K.M. Youssef, C.C. Koch, P.S. Fedkiw, Influence of pulse plating parameters on the synthesis and preferred orientation of nanocrystalline zinc from zinc sulfate electrolytes, Electrochim. Acta. $54 \quad$ (2008) 677-683. doi:10.1016/j.electacta.2008.07.048.

[40] J.F. Silva Filho, V.F.C. Lins, Crystallographic texture and morphology of an electrodeposited zinc layer, Surf. Coatings Technol. 200 (2006) 2892-2899. 
doi:10.1016/j.surfcoat.2005.04.032.

[41] B. Szczesniak, M. Cyrankowska, A. Nowacki, Corrosion kinetics of battery zinc alloys in electrolyte solutions, J. Power Sources. 75 (1998) 130-138.

[42] Z.A. Matysina, L.M. Chuprina, S.Y. Zaginaichenko, Surface structure, roughness, energy and texture of crystals, J. Phys. Chem. Solids. 53 (1992) 167-174. doi:10.1016/0022-3697(92)90024-8.

[43] S. Khorsand, K. Raeissi, M.A. Golozar, An investigation on the role of texture and surface morphology in the corrosion resistance of zinc electrodeposits, Corros. Sci. 53 (2011) 2676-2678. doi:10.1016/j.corsci.2011.04.007.

[44] J. Yu, The Influences of Organic Additives on Zinc Electrocrystallization from $\mathrm{KCl}$ Solutions, J. Electrochem. Soc. $146 \quad$ (1999) 1789-1793. doi:10.1149/1.1391844.

[45] N.A. Pangarov, Preferred orientation in electrodeposited metals, J. Electroanal. Chem. 9 (1965) 70-85. 


\section{Figures}
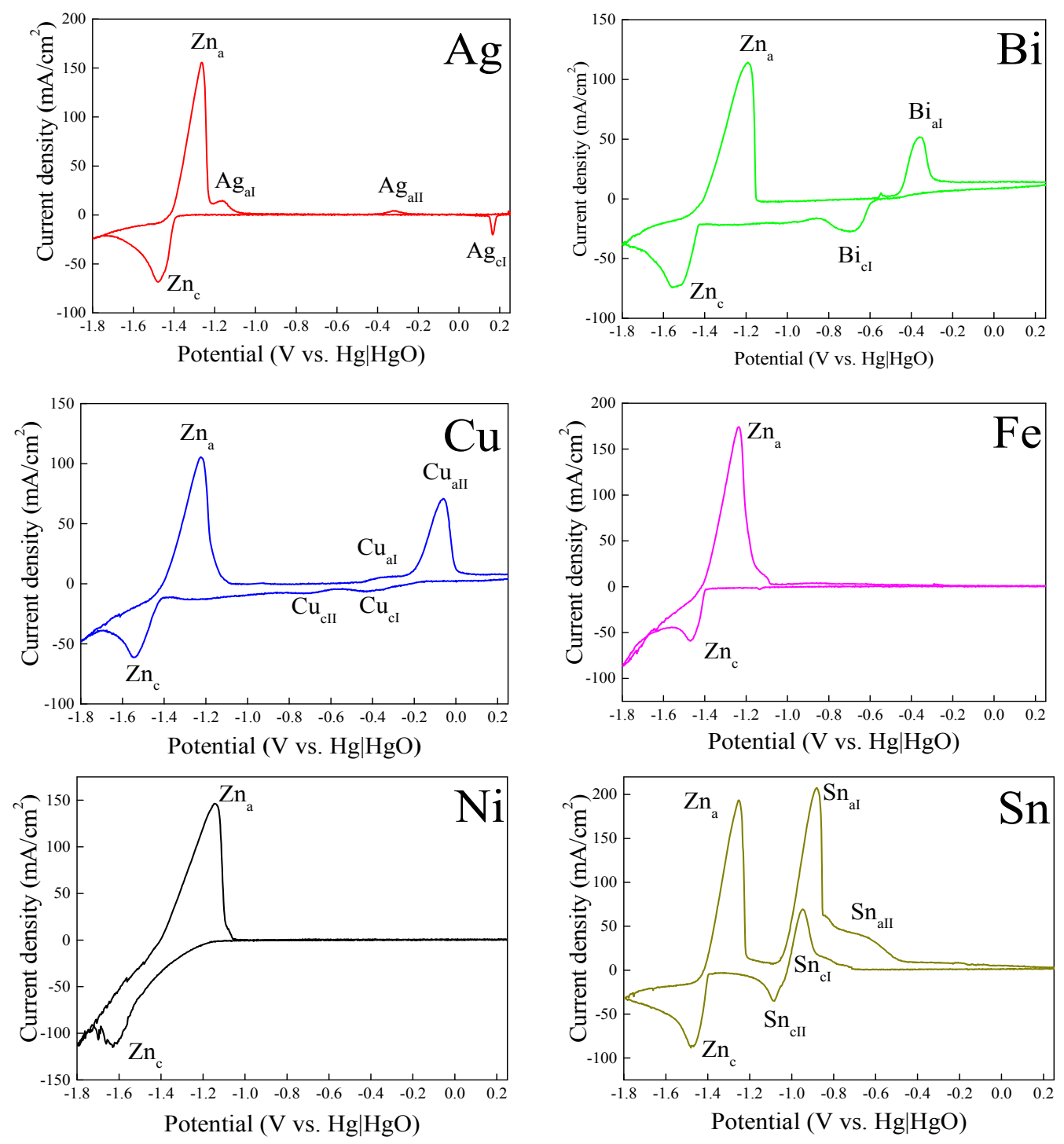

Figure 1 Cyclic voltammograms of zinc reaction on $\mathrm{Ag}, \mathrm{Bi}, \mathrm{Cu}, \mathrm{Fe}, \mathrm{Ni}$ and $\mathrm{Sn}$ rotating disk electrodes $(100 \mathrm{rpm})$ at scan rate of $10 \mathrm{mV} / \mathrm{s}$. Scan range is from $-1.8 \mathrm{~V}$ to $0.2 \mathrm{~V}$ vs.

\section{$\mathrm{Hg} \mid \mathrm{HgO}$}



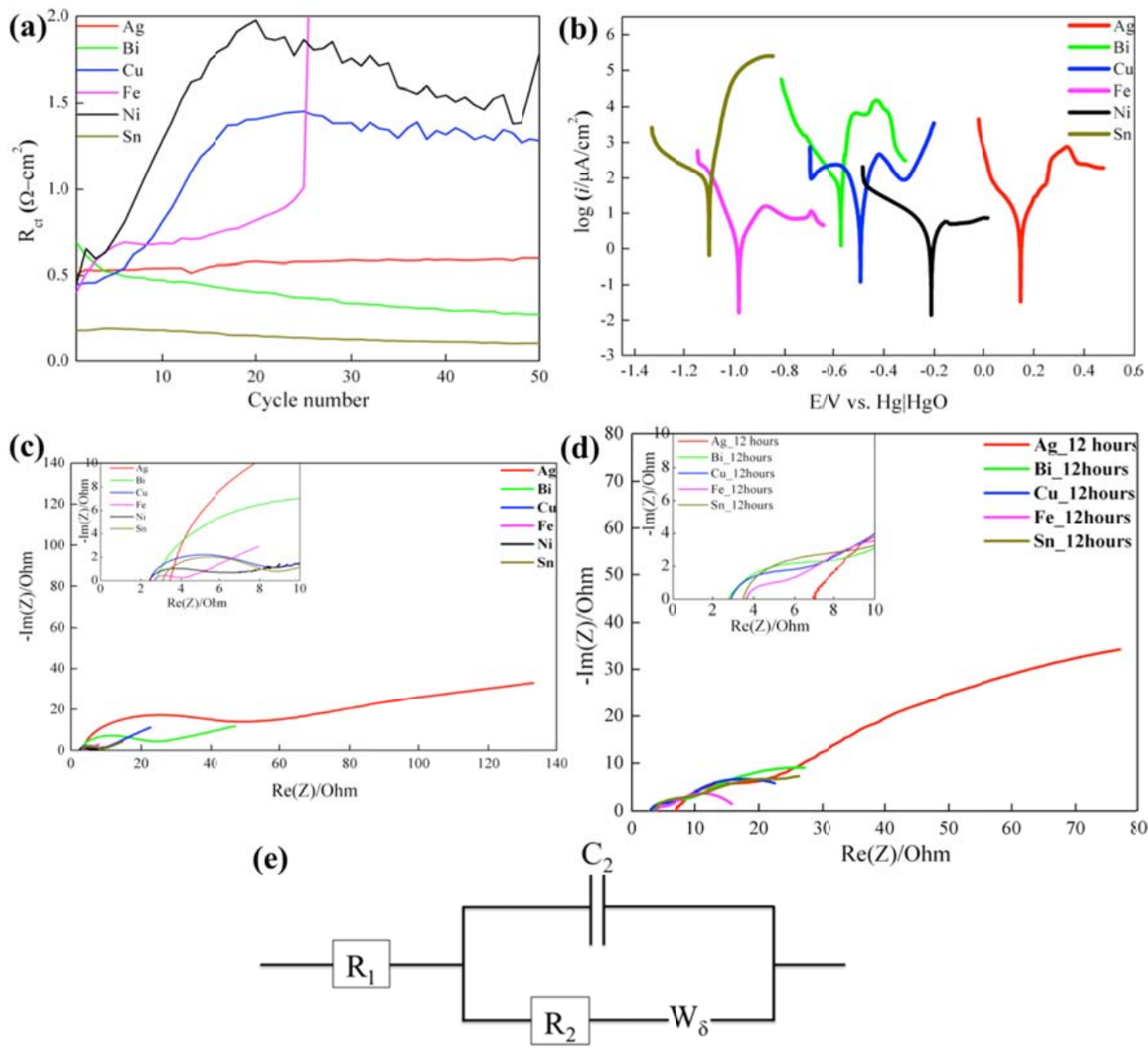

Figure 2 (a) Effect of cycle number on $\mathrm{R}_{\mathrm{ct}}$ at the start of zinc deposition on metal $\mathrm{Ag}, \mathrm{Bi}$, $\mathrm{Cu}, \mathrm{Fe}, \mathrm{Ni}$ and $\mathrm{Sn}$ substrates (charge density $=5 \mathrm{C} / \mathrm{cm}^{2}$ and $i=25 \mathrm{~mA} / \mathrm{cm}^{2}$ ) (b) Polarization curves of substrates $\mathrm{Ag}, \mathrm{Bi}, \mathrm{Cu}, \mathrm{Fe}, \mathrm{Ni}$ and $\mathrm{Sn}$ in $9 \mathrm{M} \mathrm{KOH} \mathrm{(v=0.166} \mathrm{mV/s)} \mathrm{(c)} \mathrm{Nyquist}$ plots of a zinc layer on different substrates before and (d) after 12 hours rest where the inset plots are a zoomed view. No Ni data is available after 12 hours because the zinc dissolved completely. (e) Equivalent electrical circuit of the electrochemical impedance spectroscopy from Figs. 2c-2d 


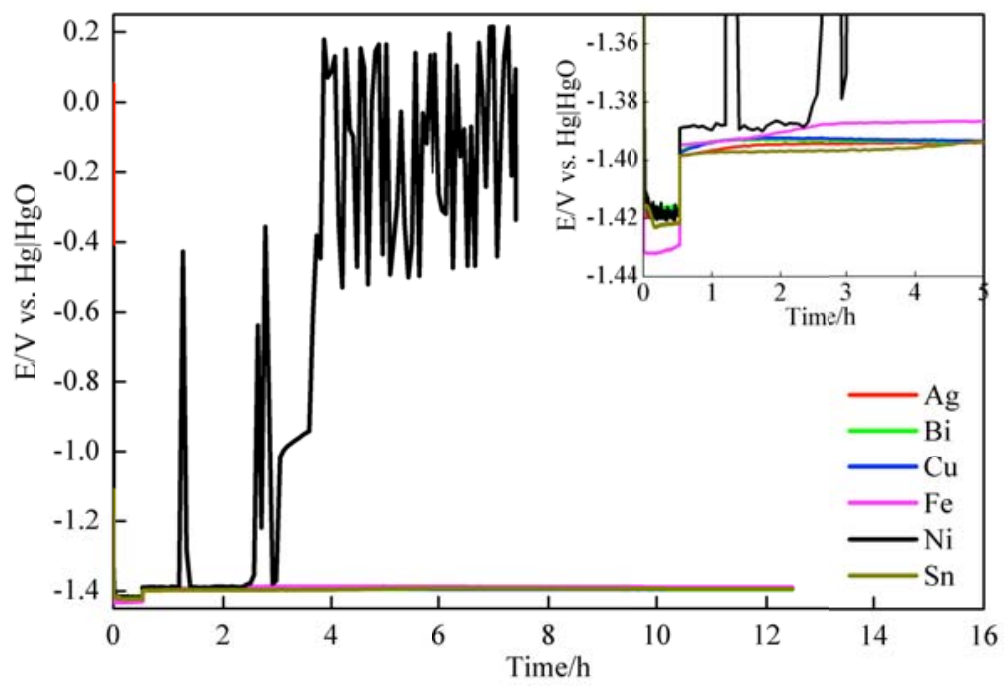

Figure 3 Self-discharge of zinc deposition on metal anodes where the inset plots are a zoomed view (After depositing zinc for $50 \mathrm{C} / \mathrm{cm}^{2}$ under $25 \mathrm{~mA} / \mathrm{cm}^{2}$ then anodes were left at $\mathrm{OCV}$ for 12 hours). The metal substrates were rotating disk electrodes. On Ni electrode, $\mathrm{Zn}$ corrodes the fastest.
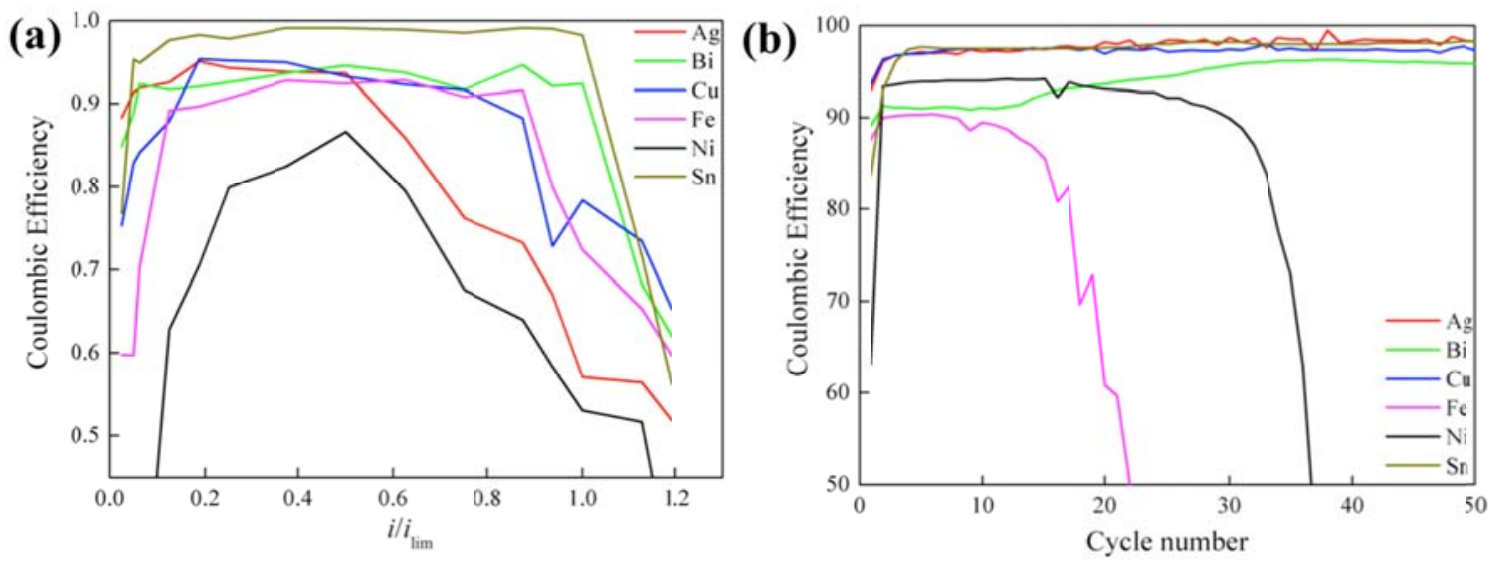

Figure 4 (a) Coulombic efficiency of zinc deposited on $\mathrm{Ag}, \mathrm{Bi}, \mathrm{Cu}, \mathrm{Fe}, \mathrm{Ni}$ and $\mathrm{Sn}$ at different current densities (charge density $=5 \mathrm{C} / \mathrm{cm}^{2}$ ) (b) Coulombic efficiency of zinc deposited on $\mathrm{Ag}, \mathrm{Bi}, \mathrm{Cu}, \mathrm{Fe}, \mathrm{Ni}$ and $\mathrm{Sn}$ as a function of cycle number (charge density=5 $\mathrm{C} / \mathrm{cm}^{2}$ and current density $i$ on charge $=-20 \mathrm{~mA} / \mathrm{cm}^{2}$ and current density $i$ on discharge $=25$ $\mathrm{mA} / \mathrm{cm}^{2}$ ) The metal substrates were RDE 

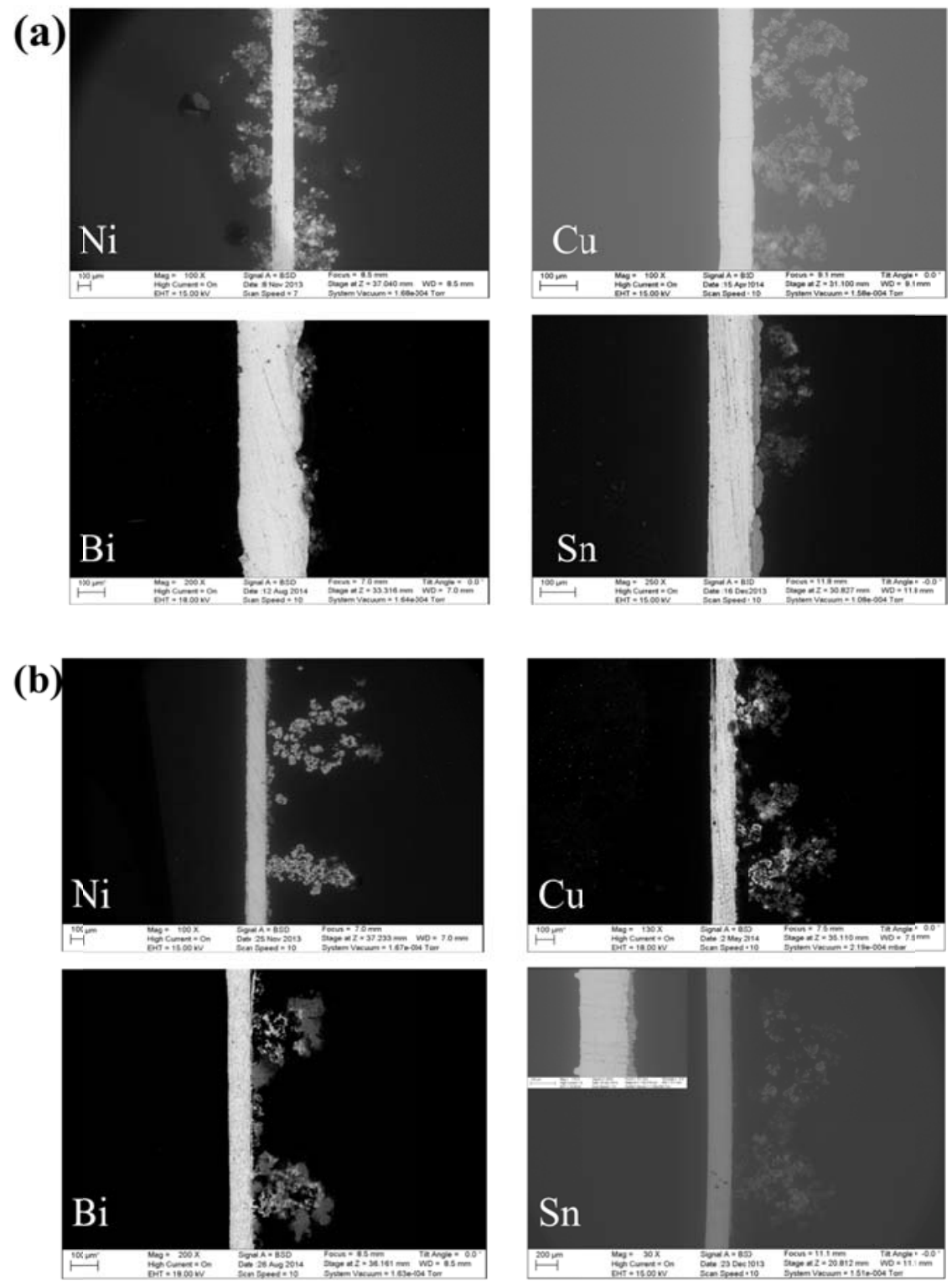

Figure 5 (a) Cross section images of zinc electrodeposition on metal substrates at the first cycle at $25 \mathrm{~mA} / \mathrm{cm}^{2}$ (b) at the sixth cycle (Charge density=50 C/cm${ }^{2}$ ) Electrode size: $1 \mathrm{in}^{2}$ 

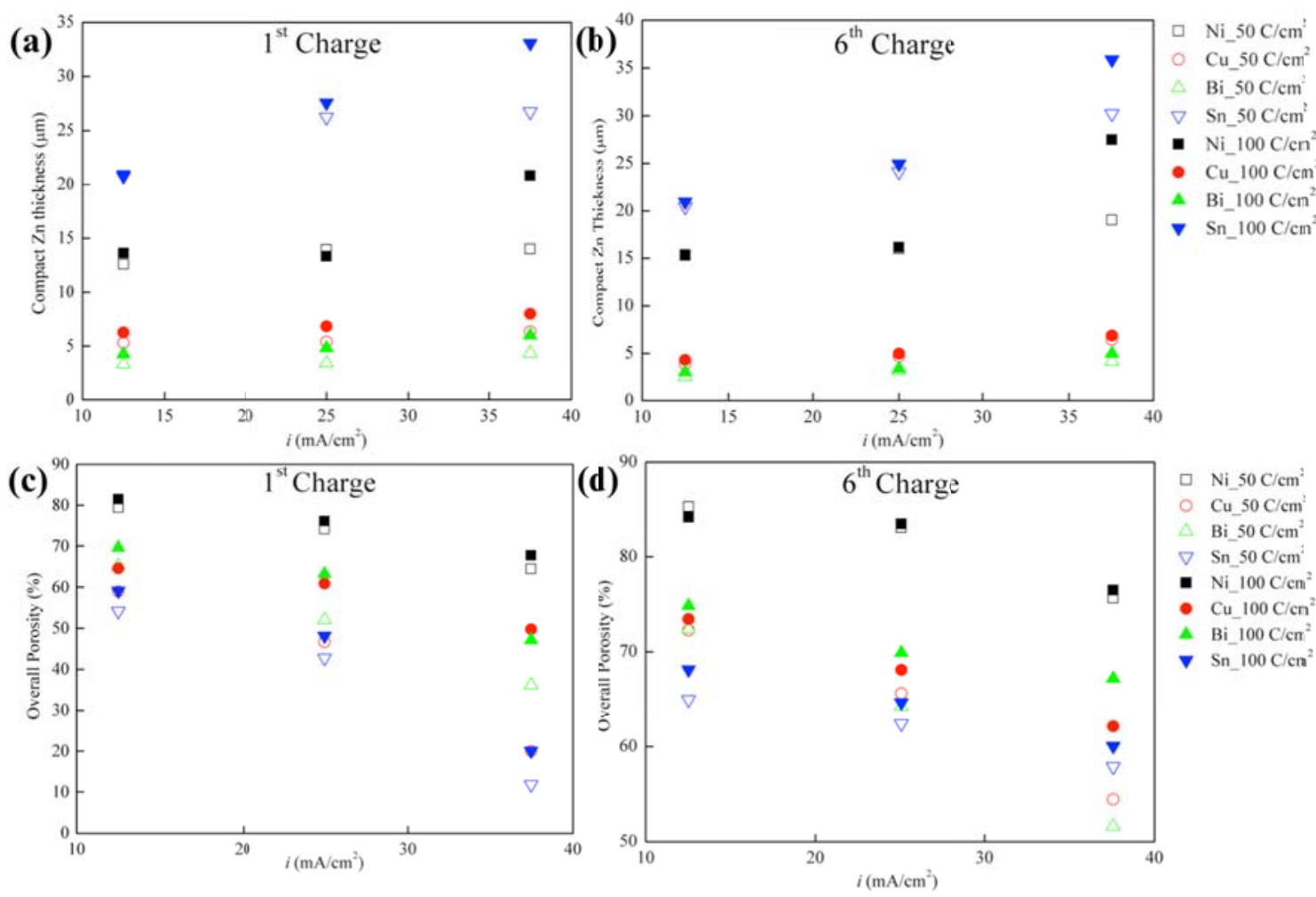

Figure 6 (a) Compact layer thickness of zinc plated on metal anodes at the 1st cycle and (b) $6^{\text {th }}$ cycle (c) Overall porosity of zinc deposition on metal anodes at the 1 st cycle and (d) $6^{\text {th }}$ cycle $\left(\right.$ Charge density $\left.=50 \mathrm{C} / \mathrm{cm}^{2} \& 100 \mathrm{C} / \mathrm{cm}^{2}\right)$ Electrode size: $1 \mathrm{in}^{2}$ 
(a)
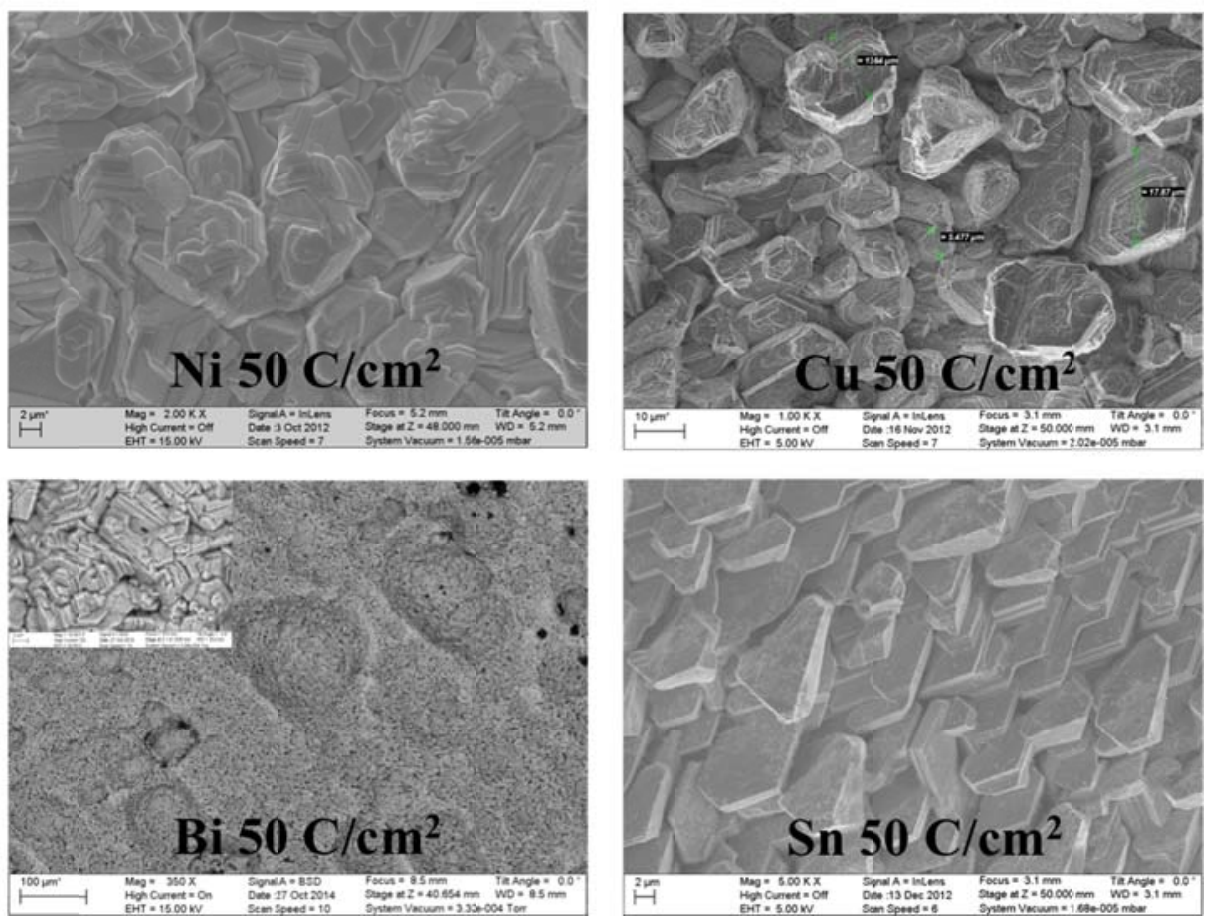

(b)
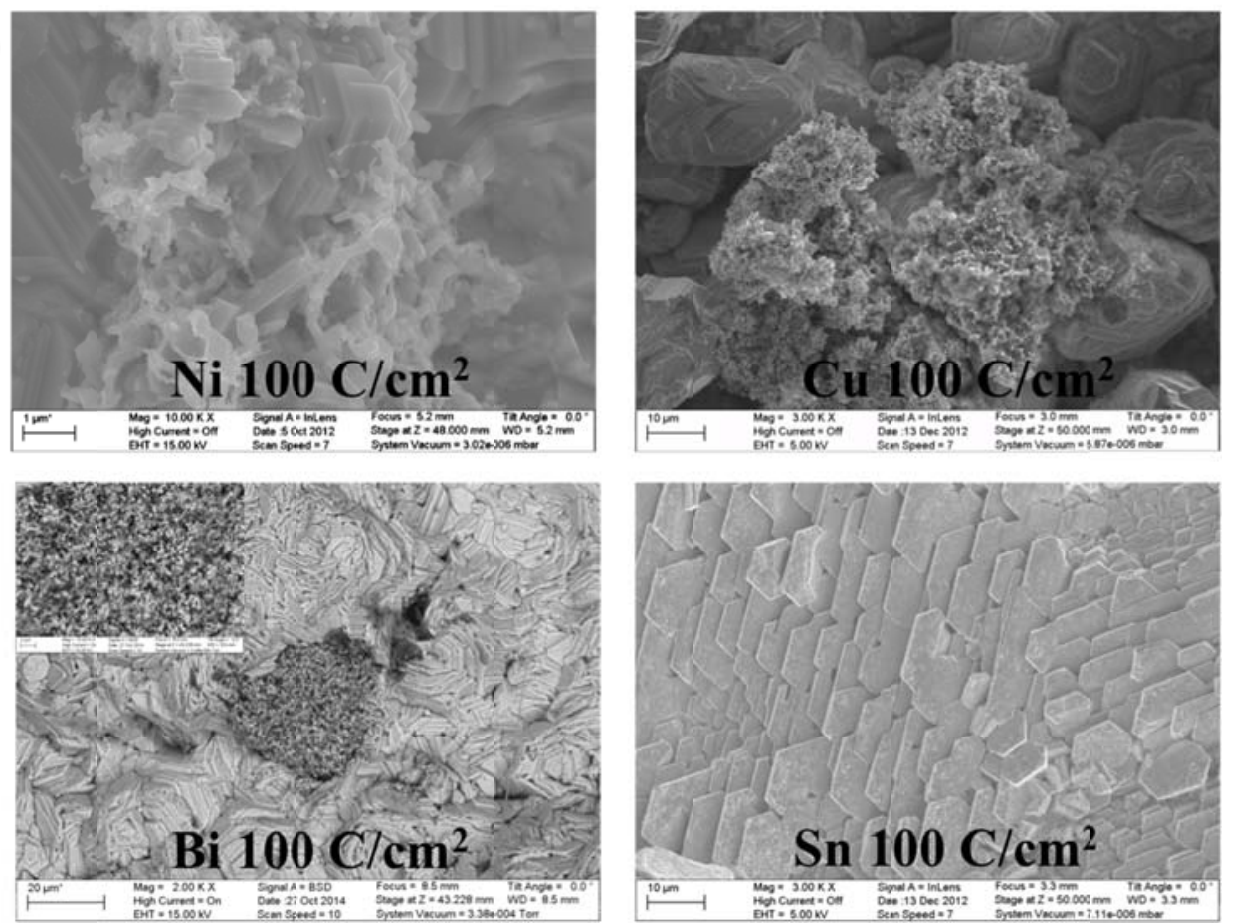

Figure 7 Surface morphology of zinc deposition on Ni, Cu, Bi and $\mathrm{Sn}$ at $i=37.5 \mathrm{~mA} / \mathrm{cm}^{2}$

(a) Charge density $=50 \mathrm{C} / \mathrm{cm}^{2}$ and (b) $100 \mathrm{C} / \mathrm{cm}^{2}$ (Electrode size: $1 \mathrm{in}^{2}$ ) 

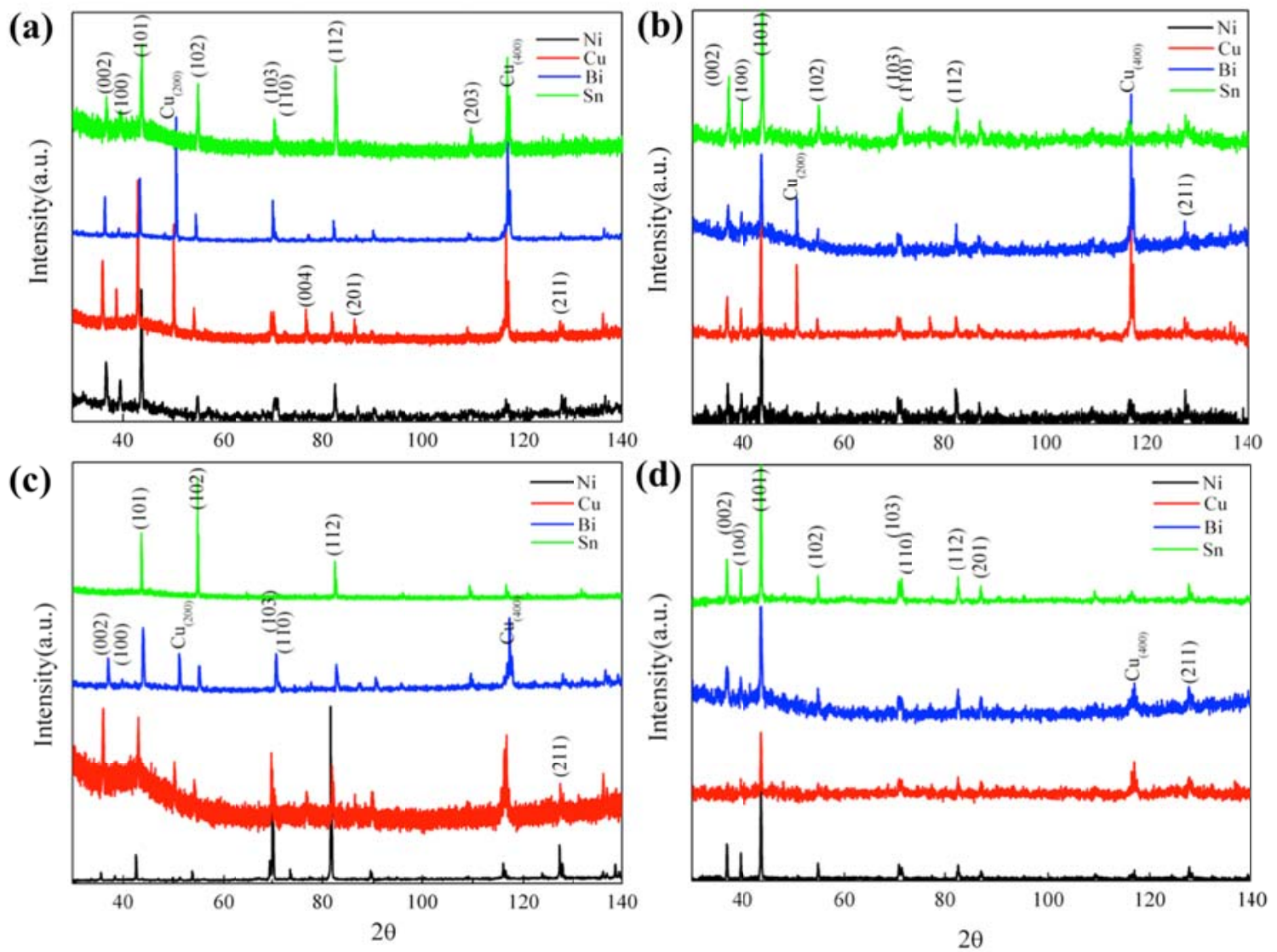

Figure 8 XRD of zinc deposition under $25 \mathrm{~mA} / \mathrm{cm}^{2}$ at (a) cycle 1 and (b) cycle 6 XRD of zinc deposition under $37.5 \mathrm{~mA} / \mathrm{cm}^{2}$ at (c) cycle 1 and (d) cycle 6 (charge density: $50 \mathrm{C} / \mathrm{cm}^{2}$ ) Electrode size: $1 \mathrm{in}^{2}$ 